\title{
HPLC METHOD IMPROVEMENT FOR 4-NONYLPHENOL DETERMINATION IN ANAEROBIC REACTORS: DECREASING SOLVENT CONSUMPTION AND WASTE GENERATION
}

\author{
Henrique S. Dornelles ${ }^{\mathrm{a}, *,\left({ }^{\circ}\right.}$, Fabrício Motteran ${ }^{\mathrm{b}}$, Isabel K. Sakamoto ${ }^{\mathrm{a}}$, Maria A. T. Adorno ${ }^{\mathrm{a}}$ and Maria Bernadete A. \\ Varesche $^{\mathrm{a}}$ \\ aDepartamento de Engenharia Hidráulica e Saneamento, Escola de Engenharia de São Carlos, Universidade de São Paulo, 13563-120 \\ São Carlos - SP, Brasil

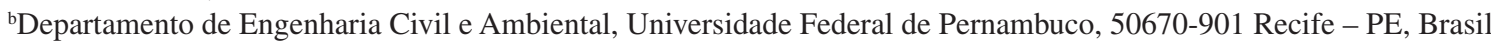

Recebido em 25/03/2020; aceito em 04/06/2020; publicado na web em 15/07/2020

\begin{abstract}
The aim of this study was to develop a chromatographic method for 4-NP determination in anaerobic batch reactors using low amount of organic solvents and also evaluate 4-NP degradation in the presence of different co-substrates. Chromatographic parameters was improved for stationary phase (C-8 column), mobile phase (acetonitrile/water solution 90:10, v:v), column temperature ( $40^{\circ} \mathrm{C}$ ), eluent flow $\left(0.8 \mathrm{~mL} \mathrm{~min}^{-1}\right)$, injection volume $(100 \mu \mathrm{L})$ and wavelengths in fluorescence detector (FLD) $\left(\lambda_{\mathrm{ex}}=225 \mathrm{~nm}\right.$ and $\left.\lambda_{\mathrm{em}}=305 \mathrm{~nm}\right)$. Solid phase extraction (SPE) was performed for sample purification with smaller amount of solvents (methanol - $2 \mathrm{~mL}$ and ethanol - $1 \mathrm{~mL}$ ) than previously reported. Reduction in reagent consumption was about 5.5 times for HPLC and about 19 times for SPE, according to previously reported. Method was validated according to the linearity (0.9951), selectivity and limits of detection and quantification were $15.7 \mu \mathrm{g} \mathrm{L}^{-1}$ and $55.6 \mu \mathrm{g} \mathrm{L}^{-1}$, respectively. The 4-NP removal in anaerobic batch reactors was higher than 50\% (4-NP initial concentration of $398 \mu \mathrm{g} \mathrm{L}^{-1}$ ). Fumarate was a better co-substrate to favor methanogenesis in the presence of 4-NP, which provided higher organic matter removal, higher methane production speed and shorter start-up time for methane production.
\end{abstract}

Keywords: endocrine disruptor; nonionic surfactant; SPE; residue; microbial diversity.

\section{INTRODUCTION}

High performance liquid chromatography (HPLC) is a technique widely used for several compounds determination such 4-NP ${ }^{1}$ and many chromatographic parameters can be varied to achieve a better detection range of the interest compounds. ${ }^{2}$ In addition to better detection, chromatographic parameters can be varied to reduce reagent consumption and consequently reduce waste generation, which enable the development of more sustainable and cheaper methods.

Surfactants make the sewage composition extremely complex, especially within commercial laundry wastewater ${ }^{3}$ and the micropollutants determination in these matrices demands a high selectivity and robustness method without losing accuracy. The 4-Nonylphenol (4-NP) determination in complex matrices was successfully accessed by HPLC technique in surface water samples, ${ }^{4-6}$ sewage ${ }^{7,8}$ and sediments. ${ }^{9}$ However, reagent consumption and waste generation have not received adequate attention. Reagent volumes per run frequently used in surface water samples are $14 \mathrm{~mL},{ }^{4} 15 \mathrm{~mL}^{6}$ and $30 \mathrm{~mL} .{ }^{10}$ In effluent samples from wastewater treatment plants (WWTP) these values may reach $35 \mathrm{~mL} .{ }^{11}$

Determination of 4-NP by HPLC requires sample preparation and solid phase extraction (SPE) is often used. However, this technique can generate even more residue than the HPLC determination itself because of the conditioning and elution steps. Reagent volumes used in SPE for sludge samples are $60 \mathrm{~mL},{ }^{12}$ while in surface water samples range from $20 \mathrm{~mL}^{13}$ to $75 \mathrm{~mL} .^{14}$ Chemical residue generated in SPE and HPLC steps demands adequate treatment and disposal, which represents a cost increase in 4-NP monitoring.

The 4-NP is a xenobiotic generated from nonionic surfactant Nonylphenol ethoxylated (NPe) degradation. This surfactant is widely used in the formulation of household cleaning products, personal care, textiles, paints, polymers, pesticide, pharmaceuticals, mining, oil recovery, pulp and paper industries. ${ }^{15}$ These substance in the environment is directly related to anthropic activities with discharge of effluents WWTP ${ }^{16}$ and when released into environment reaches rivers, ${ }^{1,17,18}$ sediments, ${ }^{19}$ estuaries, ${ }^{20}$ rain and snow, ${ }^{21}$ causing several impacts in aquatic biota and humans.

Humans are exposed to NPe through the food consumption from crops irrigated with contaminated water sources, ${ }^{22}$ by direct water ingestion, ${ }^{23}$ use of spermicides and contraceptives, contact with cleaning products and personal hygiene. ${ }^{24} \mathrm{NPe}$ is also used in polymer synthesis for plastic manufacture of containers and packaging, which can release 4-NP for food and water according with conditions of use. ${ }^{25}$

Byproducts from NPe degradation are more toxic than precursors ${ }^{26}$ and 4-NP can mimic the female hormone $17 \beta$-estradiol and compete for the same binding sites in animal cells causing endocrine system disruption. ${ }^{27}$ The $17 \beta$-estradiol is a natural hormone that influences the development and maintenance of female characteristics, ${ }^{28}$ because of this, the organisms in contact with 4-NP can trigger the most diverse reactions as aberrant cells proliferation, ${ }^{29}$ lesions in the reproductive system, ${ }^{30}$ reduction of oxytocin secretion, ${ }^{31}$ inhibition of the testosterone release, ${ }^{32}$ antiandrogenic activity ${ }^{33}$ and DNA damages. ${ }^{34}$ Face to the environmental risk of this emerging contaminant and their irreparable short and long-term damage, it is evident the urgency to investigate the effectiveness of 4-NP removal in biological systems which can irreversibly affect different ecosystems even in low concentrations.

The aim of this study was to develop a method for 4-NP determination in anaerobic reactor by HPLC-FLD and SPE techniques with lower reagent volume. Moreover, to evaluate co-substrate influence on 4-NP degradation under methanogenic conditions. 


\section{EXPERIMENTAL}

\section{Chemicals and reagents}

High purity grade (>98\%) reagents were used and ultrapure water was supplied by Milli-Q Plus Ultra System (Billerica, MA) for solutions preparation. Acetonitrile was purchased from J.T. Baker $^{\circledR}$. Methanol and ethanol were purchased from Panreac ${ }^{\circledR}$. Sodium fumarate (CAS n ${ }^{\circ}$ 17013-01-3) and 4-NP (CAS n $\left.{ }^{\circ} 104-40-5\right)$ were purchased from Sigma-Aldrich ${ }^{\circledR}$. Molar mass of 4-NP was $220.35 \mathrm{~g} \mathrm{~mol}^{-1}$ and chemical structure is shown in Figure 1.

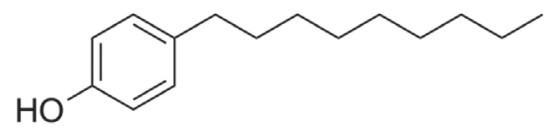

Figure 1. Molecular structure of 4-NP, sourced from Sigma-Aldrich (2020)

\section{Instrumentation and chromatographic conditions}

HPLC system (Shimadzu® Co., Kyoto Japan) equipped with LC- $10 \mathrm{AD}_{\mathrm{VP}}$ pump, FCV-10 AL $\mathrm{V}_{\mathrm{VP}}$ valve, CTO-10A $\mathrm{AP}_{\mathrm{VP}}$ oven, RF10A fluorescence detector and SCL-10A $\mathrm{AP}_{\mathrm{VP}}$ control unit were used for 4-NP determination, with Class-VP software $\left(\right.$ Shimadzu $\left.^{\circledR}\right)$ for system control operation. C-8 column (Agilent ${ }^{\circledR}$ with $5 \mu \mathrm{m}$ particle size, $15 \mathrm{~cm}$ long and $4.6 \mathrm{~mm}$ internal diameter) and C-18 column (Shimadzu ${ }^{\circledR}$ with a particle size of $5 \mu \mathrm{m}, 250 \mathrm{~mm}$ length and $4.6 \mathrm{~mm}$ diameter) were used as stationary phase.

Chromatographic conditions were tested based on previously reported, where: C- $8^{4,10,35,36}$ and C-18 columns s,8,37,38 $^{6}$ stationary phase, mobile phase (acetonitrile/water in different proportions), isocratic elution system, column temperature, eluent flow, injection volume and different wavelengths $(\lambda)$ in the fluorescence detector. Optimization of chromatographic parameters were performed with 4-NP stock solution of $1000 \mu \mathrm{g} \mathrm{L}^{-1}$ solubilized in methanol. Acetonitrile/water in the ratio of 90:10 (v/v $)^{6,39}$ and 70:30 (v/v) was tested as mobile phase in both $\mathrm{C}-8$ and $\mathrm{C}-18$ columns.

Column temperatures of $35{ }^{\circ} \mathrm{C},{ }^{35} 40{ }^{\circ} \mathrm{C}^{4}$ and $45^{\circ} \mathrm{C}$ were tested for the mobile phase flows of $0.5 \mathrm{~mL} \mathrm{~min}{ }^{-1}, 50.8 \mathrm{~mL} \mathrm{~min}{ }^{-1}$ and $1.0 \mathrm{~mL} \mathrm{~min}^{-1} .{ }^{4,6,11,36,37}$ Better mobile phase flow was chosen according to the chromatographic peak definition. The 4-NP concentrations of $2 \mu \mathrm{g} \mathrm{L}^{-1}, 5 \mu \mathrm{g} \mathrm{L}-1$ and $60 \mu \mathrm{g} \mathrm{L}^{-1}$ were performed for injection volume tests of $10 \mu \mathrm{L},{ }^{4,6,11} 30 \mu \mathrm{L}, 50 \mu \mathrm{L}$ and $100 \mu \mathrm{L} .{ }^{36}$ Injection volume was increased to achieve lower concentrations of the interest compound without overloading detection capability. Wavelengths tested in the RF10A $A_{\mathrm{XL}}$ fluorescence detector (FLD) for excitation and emission were $\lambda_{\mathrm{ex}}=220 \mathrm{~nm}$ and $\lambda_{\mathrm{em}}=315 \mathrm{~nm} ;, 10 \lambda_{\mathrm{ex}}=226 \mathrm{~nm}$ and $\lambda_{\mathrm{em}}=305 \mathrm{~nm} ;{ }^{36}$ $\lambda_{\mathrm{ex}}=230 \mathrm{~nm}$ and $\lambda_{\mathrm{em}}=320 \mathrm{~nm} ; \lambda_{\mathrm{ex}}=230 \mathrm{~nm}$ and $\lambda_{\mathrm{em}}=300 \mathrm{~nm} ; 40$ $\lambda_{\mathrm{ex}}=225 \mathrm{~nm}$ and $\lambda_{\mathrm{em}}=305 \mathrm{~nm} ; \lambda_{\mathrm{ex}}=225 \mathrm{~nm}$ and $\lambda_{\mathrm{em}}=315 \mathrm{~nm}$ and $\lambda_{\mathrm{ex}}=220 \mathrm{~nm}$ and $\lambda_{\mathrm{em}}=305 \mathrm{~nm}$.

After finding the optimized conditions for 4-NP determination each parameter tested was fixed and used for the next test. Method validation was performed with simulated substrate plus 4-NP.

\section{Method validation}

Method validation was based on the quality parameters proposed by the United States Environmental Protection Agency (USEPA) in Method 8310 - Polynuclear Aromatic Hydrocarbons, for HPLC-FLD. The parameters evaluated were selectivity, linearity, limits of detection (LOD) and quantification (LOQ), accuracy, precision and repeatability. Analytical curve of 4-NP was performed in simulated substrate consisted of yeast extract $\left(500.0 \mathrm{mg} \mathrm{L}^{-1}\right)$, sodium bicarbonate
(400.0 mg L $\left.\mathrm{mg}^{-1}\right), \mathrm{NaCl}\left(250.0 \mathrm{mg} \mathrm{L}^{-1}\right), \mathrm{MgCl}_{2} \cdot 6 \mathrm{H}_{2} \mathrm{O}\left(7.0 \mathrm{mg} \mathrm{L}^{-1}\right)$ and $\mathrm{CaCl}_{2} \cdot 2 \mathrm{H}_{2} \mathrm{O}\left(4.5 \mathrm{mg} \mathrm{L}^{-1}\right){ }^{41}$

Method selectivity was verified through the technique of matrix match $^{42}$ using simulated substrate plus 4-NP and a solution of simulated substrate free of analyte. Linearity was evaluated by the analytical curve mean with mathematical ratio among analytical signal (chromatographic areas) and the theoretical (nominal) 4-NP concentration. Sixteen 4-NP concentrations ware analyzed in quintuplicate: $55.6 \mu \mathrm{g} \mathrm{L}^{-1} ; 83.3 \mu \mathrm{g} \mathrm{L}^{-1} ; 100.0 \mu \mathrm{g} \mathrm{L}^{-1} ; 166.7 \mu \mathrm{g} \mathrm{L}^{-1}$; $200.0 \mu \mathrm{g} \mathrm{L}^{-1} ; 250.0 \mu \mathrm{g} \mathrm{L}^{-1} ; 375.0 \mu \mathrm{g} \mathrm{L}^{-1} ; 500.0 \mu \mathrm{g} \mathrm{L}^{-1} ; 625.0 \mu \mathrm{g} \mathrm{L}^{-1}$; $750.0 \mu \mathrm{g} \mathrm{L}^{-1} ; 875.0 \mu \mathrm{g} \mathrm{L}{ }^{-1} ; 1250.0 \mu \mathrm{g} \mathrm{L}^{-1} ; 1750.0 \mu \mathrm{g} \mathrm{L}^{-1} ; 2250.0 \mu \mathrm{g} \mathrm{L}^{-1}$; $2750.0 \mu \mathrm{g} \mathrm{L}^{-1}$ and $3250.0 \mu \mathrm{g} \mathrm{L}^{-1}$. Precision was calculated by relative standard deviation (RSD\%) of the analyte, ${ }^{43}$ ranging from $55.6 \mu \mathrm{g} \mathrm{L}{ }^{-1}$ to $3250.0 \mu \mathrm{g} \mathrm{L}^{-1}$. LOD was calculated as 3 times the signal-to-noise. LOQ was set as the lowest concentration of the analytical curve.

\section{Sample pretreatment by Solid Phase Extraction (SPE)}

SPE was used for sample purification before HPLC injection. Cartridges were coupled to Vacuum Manifold Processing Station (Agilent Technologies ${ }^{\circledR}$ - Santa Clara, CA) and submitted to 5 bars of pressure with vacuum pump filtration (Prismatec ${ }^{\circledR}$ - Itu, SP). SPE Cartridges tested $(500 \mathrm{mg}, 6 \mathrm{~mL}$ ) were C18-ODS (Agilent Technologies ${ }^{\circledR}$ - Santa Clara, California), C18-endcapped (ec) (Macherey-Nagel ${ }^{\circledR}$ Düren, Germany) and Alumina (Supelco ${ }^{\circledR}$ Darmstadt, Germany). All SPE cartridges were conditioned and eluted with pure ethanol, methanol and ultrapure water.

Simulated substrate ${ }^{41}$ plus $4-\mathrm{NP}$ at $2999.3 \pm 74.9 \mu \mathrm{g} \mathrm{L}^{-1}$ was quintuplicate filtered in membranes $(0.22 \mu \mathrm{m}$ porosity) of cellulose acetate, regenerated cellulose and glass fiber as an alternative to reduce procedures and method costs. Concentrations average after filtration were statistically compared by Tukey test at $5 \%$ of error probability.

Samples from anaerobic batch reactors with high suspended solids concentration were centrifuged in glass flasks at $2500 \mathrm{rpm}$ for $10 \mathrm{~min}$ for further extraction in SPE cartridges and HPLC determination.

\section{Anaerobic batch reactors}

Anaerobic batch reactors (Duran ${ }^{\circledR}$ flasks) with $500 \mathrm{~mL}$ of total volume ( $250 \mathrm{~mL}$ of headspace and $250 \mathrm{~mL}$ of reaction volume) were operated in triplicate. Reactors were fed with simulated substrate identical to that used for method validation plus co-substrate of each assay. Methanogenic potential of anaerobic sludge in 4-NP presence was assessed in ethanol, methanol and sodium fumarate as co-substrates and the concentration was standardized according to ethanol concentration $\left(200 \mathrm{mg} \mathrm{L}^{-1}\right)$ proposed by Macedo et al., ${ }^{44}$ equivalent to $4.3 \mathrm{mM}$. Thus, the theoretical value of each co-substrate was $200 \mathrm{mg} \mathrm{L}^{-1}$ of ethanol, $140 \mathrm{mg} \mathrm{L}^{-1}$ of methanol and $600 \mathrm{mg} \mathrm{L}^{-1}$ of sodium fumarate. Control reactors (no 4-NP addition) were named $\mathrm{EtOH}, \mathrm{MeOH}$ and Fum for the ethanol, methanol and fumarate assays, respectively. Reactors with 4-NP addition were named $\mathrm{EtOH}_{\mathrm{NP}}$, $\mathrm{MeOH}_{\mathrm{NP}}$ and $\mathrm{Fum}_{\mathrm{NP}}$ for ethanol, methanol and sodium fumarate addition, respectively. All reactors followed the same operation procedure.

Batch reactors were inoculated with anaerobic granular sludge from up-flow anaerobic sludge blanket (UASB) reactor used in the treatment of poultry slaughterhouse wastewater (Pereira, São Paulo, Brazil). Volatile suspended solids concentration (VSS) within reactional volume was $2 \mathrm{~g} \mathrm{~L}^{-1}$, similar to that used by Motteran et al. ${ }^{45}$ Before reactors inoculation, anaerobic sludge was acclimated at $30^{\circ} \mathrm{C}$ for soluble organic matter consumption, until stabilization of the methane production (10 days). After inoculation the reactors 
were submitted to $\mathrm{N}_{2}$ flow (100\%) for 10 minutes, closed with butyl cap and plastic thread and kept under $180 \mathrm{rpm}$ shaking at $30 \pm 1{ }^{\circ} \mathrm{C}$. Biogas composition $\left(\mathrm{H}_{2}, \mathrm{CH}_{4}\right.$ and $\left.\mathrm{CO}_{2}\right)$, organic matter (chemical oxygen demand - COD), pH, alkalinity and 4-NP initial and final concentration were performed in the reactors.

\section{Physicochemical analysis}

Organic matter (COD), $\mathrm{pH}$ and alkalinity were performed by Standard Methods for Water and Wastewater Analysis. ${ }^{46}$ Biogas composition was performed by gas chromatograph model GC 2010 (Shimadzu ${ }^{\circledR}$, Columbia, MD), equipped with thermal conductivity detector (TCD), Supelco Carboxen ${ }^{\circledR} 1010$ Plot column (30 mm x $0.53 \mathrm{~mm}$ external diameter, $0.30 \mu \mathrm{m}$ thick), using argon as carrier gas $\left(5.66 \mathrm{~mL} \mathrm{~min}^{-1}\right)$. Injector and detector temperatures were $220{ }^{\circ} \mathrm{C}$ and $230{ }^{\circ} \mathrm{C}$, respectively. Oven temperature ranged from $130{ }^{\circ} \mathrm{C}$ to $135^{\circ} \mathrm{C}$ at $46{ }^{\circ} \mathrm{C} \mathrm{min}{ }^{-1}$ ( 6 min of run time). Headspace samples $(0.5 \mathrm{~mL})$ were collected from pressurized batch reactors with locking gastight syringe and immediately analyzed.

\section{Molecular biology analysis}

The DNA from the batch reactor biomass samples and inoculum was extracted using a FastDNA TM SPIN Kit for Soil DNA Extraction (MP Biomedicals ${ }^{\circledR}$, Illkirch, France) according to the manufacturer's instructions. The set of primers in polymerase chain reaction (PCR) were 968 FGC - 1401R for the Bacteria Domain ${ }^{47}$ and 1100FGC 1400R for the Archaea Domain. ${ }^{48}$

Denaturing gradient gel electrophoresis (DGGE) was performed on the DCode TM Universal Mutation Detection System (Bio-Rad ${ }^{\circledR}$, California, USA). Denaturing gradient ranged from $45 \%$ to $65 \%$ on polyacrylamide gel. ${ }^{49}$ The DGGE ran for 16 hours at temperature of $60{ }^{\circ} \mathrm{C}$ to $75 \mathrm{~V}$. DGGE bands profile was read by Photo documentation system (L.PixTouch - Loccus Biotechnology ${ }^{\circledR}$, Cotia, São Paulo) under UV exposure of $254 \mathrm{~nm}$.

Similarity coefficient (Pearson's correlation) and the UPGMA dendrogram (Unweighted Pair Group Method using Arithmetic averages) were performed from the DGGE band profile by BioNumerics ${ }^{\circledR}$ software version 7.3 (Applied Maths ${ }^{\circledR}$, Sint-MartensLatem, Belgium). Ecological indices were calculated by Past software. ${ }^{50}$

\section{Statistical treatment of experimental data}

Experimental data were submitted to analysis of variance (ANOVA) and the comparison of the means were performed by Tukey test at $5 \%$ probability of error ( $p$-value: 0.05 ). Biogas production were fitting by modified Gompertz equation (Eq. 1), ${ }^{51,52}$ determining the potential methane production, cumulative methane production, methane production rate and start-up time of methane production, where: $\mathrm{M}=$ cumulative methane production $(\mu \mathrm{mol}) ; \mathrm{P}=$ potential methane production $(\mu \mathrm{mol}) ; \mathrm{Rm}=$ methane production rate $\left(\mu \mathrm{mol} \mathrm{h} \mathrm{h}^{-1}\right)$; $\lambda=$ start-up time for methane production (hours); $\mathrm{t}=$ time (hours) and $\mathrm{e}=$ Euler number (2.71828).

$$
M=P \exp \left\{-\exp \left[\frac{R m e}{P}(\lambda-t)+1\right]\right\}
$$

The parameters $\mathrm{P}, \mathrm{Rm}$ and $\lambda$ were calculated by OriginPro ${ }^{\circledR} 8.1$ software (OriginLab Corporation ${ }^{\oplus}$, Northampton, Massachusetts) and performed over 100 interactions to converge data using the mathematical model mentioned above.

\section{RESULTS AND DISCUSSION}

\section{Chromatographic parameters determination}

Well-defined 4-NP peaks were observed when C-8 and $\mathrm{C}-18$ columns were used and retention time ranged according to temperature variation $\left(35^{\circ} \mathrm{C}, 40{ }^{\circ} \mathrm{C}\right.$ and $\left.45^{\circ} \mathrm{C}\right)$ and elution flows $\left(0.5 \mathrm{~mL} \mathrm{~min}^{-1}, 0.8 \mathrm{~mL} \mathrm{~min}^{-1}\right.$ and $\left.1.0 \mathrm{~mL} \mathrm{~min}^{-1}\right)$ (Table 1), for both chromatographic columns. Largest 4-NP chromatographic areas were verified for $\mathrm{C}-18$ column, however, with longer running time, larger base width and lower height compared to $\mathrm{C}-8$ column. These results make C-8 column a better stationary phase to increase 4-NP detection and decrease the costs.

Cruceru et al. ${ }^{4}$ also applied C-8 column and HPLC-FLD for 4-NP determination in surface water samples. However, these authors used $1.0 \mathrm{~mL} \mathrm{~min}^{-1}$ for injection flow, eluents ratio of 65:35 (acetonitrile/water, v/v), $10 \mu \mathrm{L}$ of injection volume and wavelengths of $\lambda_{\mathrm{ex}}=220 \mathrm{~nm}$ and $\lambda_{\mathrm{em}}=315 \mathrm{~nm}$. These parameters provided a longer running time (14 min) compared to the present study ( $8 \mathrm{~min}$ ). In contrast, Araujo et al. ${ }^{6}$ used C-18 column for 4-NP determination in river samples by HPLC with ultraviolet detection (UV) and eluents ratio similar to this study (acetonitrile/water at 90:10, v/v); but they achieve a longer running time (15 $\mathrm{min}$ ) probably because of the HPLC flow and stationary phase. Both $\mathrm{C}-18$ and $\mathrm{C}-8$ reverse phase columns can be applied for 4-NP determination in complex matrices, however, short column led to reduce solvent consumption and the total time of analysis..$^{53}$ So, this study chose $\mathrm{C}-8$ column as stationary phase due shorter running time when compared with $\mathrm{C}-18$ column.

Table 1. Response values of each chromatographic parameters for 4-NP determination applying acetonitrile/water $(90: 10, \mathrm{v} / \mathrm{v})$ as mobile phase

\begin{tabular}{|c|c|c|c|c|}
\hline Column & $\begin{array}{c}\text { Temperature } \\
\left({ }^{\circ} \mathrm{C}\right)\end{array}$ & $\begin{array}{c}\text { Flow }(\mathrm{mL} \\
\left.\min ^{-1}\right)\end{array}$ & $\begin{array}{l}\text { Retention time } \\
\quad(\min )\end{array}$ & Area \\
\hline \multirow{9}{*}{ C-8 } & \multirow{3}{*}{35} & 1.0 & 3.02 & $3.20 \mathrm{E} 6$ \\
\hline & & 0.8 & 3.79 & $4.01 \mathrm{E} 6$ \\
\hline & & 0.5 & 6.07 & $6.52 \mathrm{E} 6$ \\
\hline & \multirow{3}{*}{40} & 1.0 & 2.88 & 3.17 E6 \\
\hline & & 0.8 & 3.58 & $4.12 \mathrm{E} 6$ \\
\hline & & 0.5 & 5.73 & $6.48 \mathrm{E} 6$ \\
\hline & \multirow{3}{*}{45} & 1.0 & 2.77 & $3.20 \mathrm{E} 6$ \\
\hline & & 0.8 & 3.46 & 4.04 E6 \\
\hline & & 0.5 & 5.54 & $6.45 \mathrm{E} 6$ \\
\hline \multirow{9}{*}{ C-18 } & \multirow{3}{*}{35} & 1.0 & 5.96 & $3.98 \mathrm{E} 6$ \\
\hline & & 0.8 & 7.55 & $5.01 \mathrm{E} 6$ \\
\hline & & 0.5 & 12.07 & 7.85 E6 \\
\hline & \multirow{3}{*}{40} & 1.0 & 5.68 & 3.93 E6 \\
\hline & & 0.8 & 7.21 & 4.92 E6 \\
\hline & & 0.5 & 11.22 & 8.32 E6 \\
\hline & \multirow{3}{*}{45} & 1.0 & 5.37 & $4.08 \mathrm{E} 6$ \\
\hline & & 0.8 & 6.69 & $5.12 \mathrm{E} 6$ \\
\hline & & 0.5 & 10.67 & 8.19 E6 \\
\hline
\end{tabular}

Column temperature and mobile phase flow were extremely important parameters for 4-NP determination. Lower mobile phase flow increased the chromatographic area but enlarged the peak base, which may implicate method selectivity. Column temperature had similar behavior to mobile phase flow: increasing column temperature decreased the retention time of all the components. However, 
temperatures above $40{ }^{\circ} \mathrm{C}$ reduced the chromatographic area and increased base width, similar to those data reported by Xie et al. ${ }^{11}$ This result may be explained by that temperature changes mobile phase viscosity and solvent solubility. Thus, increasing temperature, mobile phase viscosity will be reduced, the mass transfer increased and the pressure reduced. ${ }^{54}$

Optimized chromatographic parameters for 4-NP determination by HPLC-FLD were: C-8 column with temperature of $40{ }^{\circ} \mathrm{C}$ (Figure 2B), mobile phase flow of $0.8 \mathrm{~mL} \mathrm{~min}^{-1}$ (acetonitrile/water 90:10, v/v) (Figure $2 \mathrm{~A}$ ), injection volume of $100 \mu \mathrm{L}$ (Figure $2 \mathrm{C}$ ) and wavelengths for the fluorescence detector of $\lambda_{\mathrm{ex}}=225 \mathrm{~nm}$ and $\lambda_{\text {em }}=305 \mathrm{~nm}$ (Figure $2 \mathrm{D}$ ), which provided simple and feasible conditions for analyte determination in complex matrices such as anaerobic reactors effluents.

Eluents proportion featuring optimized detection conditions provided 3.6 minutes of 4-NP retention time and $8.0 \mathrm{~min}$ of run time was set to ensure system stability and column cleaning. Residue amount generated per sample was $6.4 \mathrm{~mL}$, basing on elution
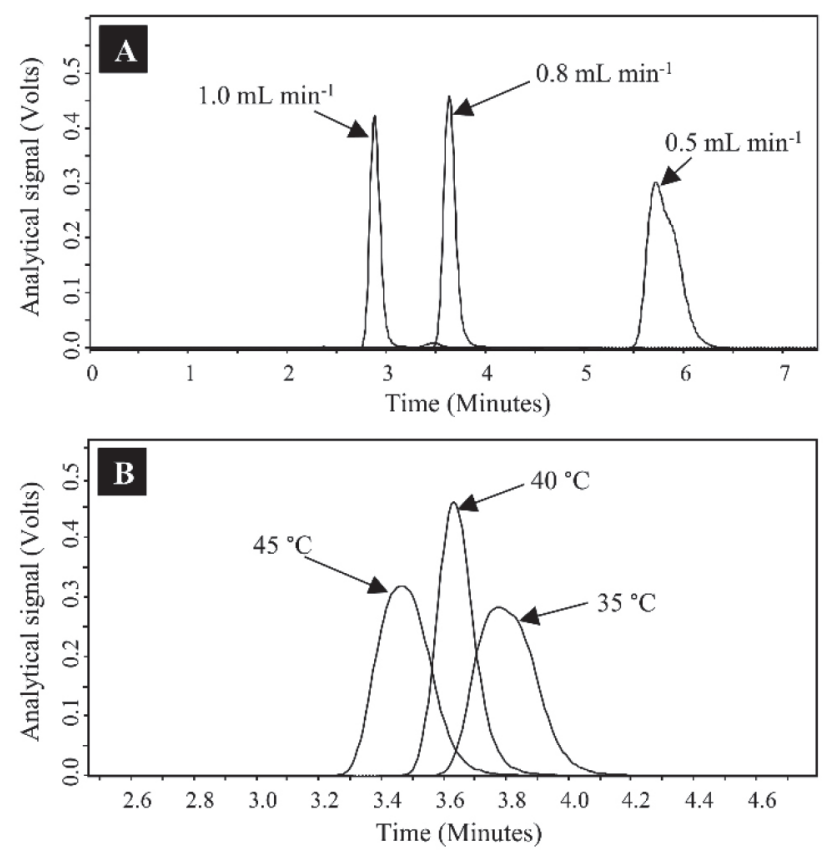

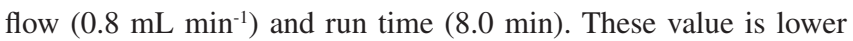
than previously reported, which ranged from $14 \mathrm{~mL}^{4}$ to $35 \mathrm{~mL},{ }^{11}$ which is about 5.5 times the volume used in the present study (6.4 mL) (Table 2). This finding support that the chromatographic conditions optimization can also decrease reagent consumption and, consequently, decrease the residue generation and analysis costs.

\section{Sample treatment}

Wide variety of toxic compounds are found in anaerobic reactors used for xenobiotic removal, especially in wastewater from commercial laundry, ${ }^{3}$ which makes it a high complexity matrix an difficult the compounds determination at low concentrations such as 4-NP. According to the EPA, ${ }^{55}$ high purity degree is required for samples analyzed by HPLC to not underestimate the analyte concentration or damages the instrument. The Standard Methods for the Examination of Water and Wastewater ${ }^{46}$ recommend filtration membranes (porosity greater than $0.22 \mu \mathrm{m}$ ) for samples treatment to
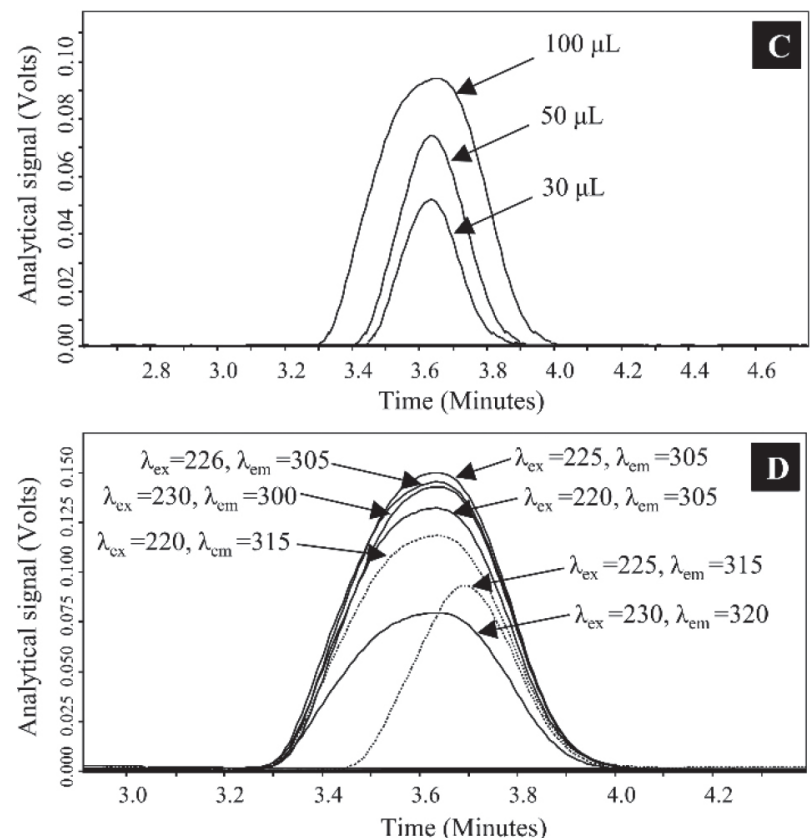

Figure 2. Chromatograms of 4-NP on C-8 column with acetonitrile/water $(90: 10, v / v)$ as mobile phase, (A) temperature of $40^{\circ} \mathrm{C}$ and flows of $0.5 \mathrm{~mL} \mathrm{~min}{ }^{-1}$, 0.8 $\mathrm{mL} \mathrm{min} \mathrm{m}^{-1}$ and $1.0 \mathrm{~mL} \mathrm{~min} \mathrm{~m}^{-1}$; (B) flow of $0.8 \mathrm{~mL} \mathrm{~min} \mathrm{~m}^{-1}$ and temperatures of $35^{\circ} \mathrm{C}, 40^{\circ} \mathrm{C}$ and $45^{\circ} \mathrm{C} ;(\mathrm{C})$ different injection volumes with flow of $0.8 \mathrm{~mL} \mathrm{~min}{ }^{-1}$; (D) detector wavelength variation with injection volume of $100 \mu \mathrm{L}$ and flow of $0.8 \mathrm{~mL} \mathrm{~min}^{-1}$

Table 2. Chromatographic parameters previously reported for 4-NP determination by HPLC

\begin{tabular}{|c|c|c|c|c|c|c|}
\hline Parameters & Cruceru et al. ${ }^{4}$ & Araujo et al. ${ }^{6}$ & Liu et $a .^{9}$ & Barahona et al..$^{35}$ & Xie et al. ${ }^{10}$ & Present study \\
\hline Instrument & HPLC-FLD & HPLC-UV & HPLC-FLD & HPLC-FLD & HPLC-UV & HPLC-FLD \\
\hline Column & C-8 & C-18 & C-8 & C-8 & APS-2 & $\mathrm{C}-8$ \\
\hline Temperature $\left({ }^{\circ} \mathrm{C}\right)$ & 40 & $*$ & $*$ & $*$ & 30 & 40 \\
\hline \multirow[t]{2}{*}{$\lambda(\mathrm{nm})$} & Ex: 220 & 225 & Ex: 220 & Ex: 226 & 277 & Ex: 225 \\
\hline & Em: 315 & & Em: 315 & Em: 305 & & Em: 305 \\
\hline Flow rate $\left(\mathrm{mL} \mathrm{min}^{-1}\right)$ & 1.0 & 1.0 & 3.0 & 1.0 & 1.0 & 0.8 \\
\hline Mobile phase (v/v) & ACN/UW (65:35) & ACN/UW (90:10) & ACN/UW (70:30) & ACN/UW (65:35) & iPrOH, HEX, DCM & ACN/UW (90:10) \\
\hline Injection volumes $(\mu \mathrm{L})$ & 10 & 10 & $*$ & 100 & 10 & 100 \\
\hline Run time (min) & 14 & 15 & 10 & 15 & 35 & 8 \\
\hline Solvent by run (mL) & 14 & 15 & 30 & 15 & 35 & 6.4 \\
\hline
\end{tabular}

ACN - Acetonitrile; $\lambda$ - Wavelength; FLD - Fluorescence Detection; UV - Ultraviolet Detection; UW - Ultrapure Water; iPrOH - Isopropanol; HEX - Hexane; DCM - Dichloromethane; * - unreported results. 
remove suspended solids or particulate matter present in the liquid medium. Filtration membranes were tested to evaluate the 4-NP adsorption and the percentage was higher than $80 \%$ for all membranes tested. After 4-NP control solution filtration with $2999.3 \pm 74.9 \mu \mathrm{g} \mathrm{L}^{-1}$, concentrations of $270.5 \pm 83.1 \mu \mathrm{g} \mathrm{L}^{-1}, 480.5 \pm 159.3 \mu \mathrm{g} \mathrm{L} \mathrm{L}^{-1}$ and $606.2 \pm 223.6 \mu \mathrm{g} \mathrm{L}^{-1}$ were recovered through membranes of cellulose, regenerated cellulose and glass fiber, respectively (Table 3 ).

Filtration membranes were applied for sample pretreatment by many researchers for 4-NP determination in surface water, ${ }^{1,4,10,13,14,18,20,56}$ sediments ${ }^{12,19}$ and effluent from wastewater treatment plants. ${ }^{11,57,58}$ However, the present study noticed high 4-NP adsorption in all filtration membranes tested, as shown in Table 3. These finding raise important implication in 4-NP determination and strongly suggest that no type of membrane can be used to samples pretreatment.

Due to the high 4-NP adsorption in filtration membranes, sample pretreatment was performed by SPE cartridges and a greater 4-NP recovery $(100.7 \pm 9.1 \%)$ occurred for C-18 ODS. Cartridge was conditioned with $2 \mathrm{~mL}$ of methanol and eluted with $1 \mathrm{~mL}$ of ethanol followed by washing with $1 \mathrm{~mL}$ of ultrapure water (Figure 3 ). This purification procedure was efficient to remove impurities that affect the chromatographic analysis.
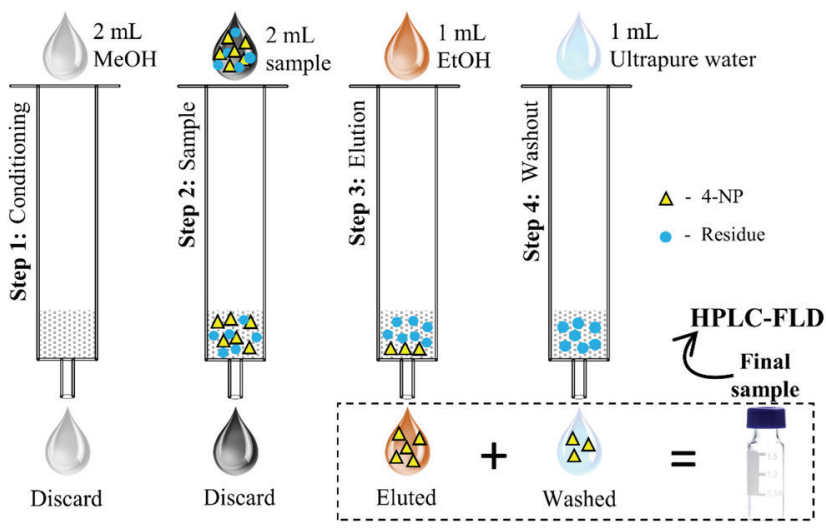

Figure 3. Sample purification procedure by Solid Phase Extraction cartridges

The clean-up step was not added because there was no identification of any other chromatographic peak in the same 4-NP retention time. The use of SPE in this study was necessary to remove solid particles larger than $0.2 \mu \mathrm{m}$ since high adsorption of 4-NP was detected in filtration membranes that had this purpose, according to discussed in Table 3.

There was no residual 4-NP concentration in the liquid phase after passing the sample through the C-18 ODS cartridge, which means that target compound was completely adsorbed. A second elution was performed to confirm the extraction method efficiency and the analyte
(4-NP) was not detected, indicating that entire 4-NP concentration added to cartridge was recovered to liquid phase after first elution ( $1 \mathrm{~mL}$ of ethanol followed by $1 \mathrm{~mL}$ of ultrapure water) (Figure 4 ).

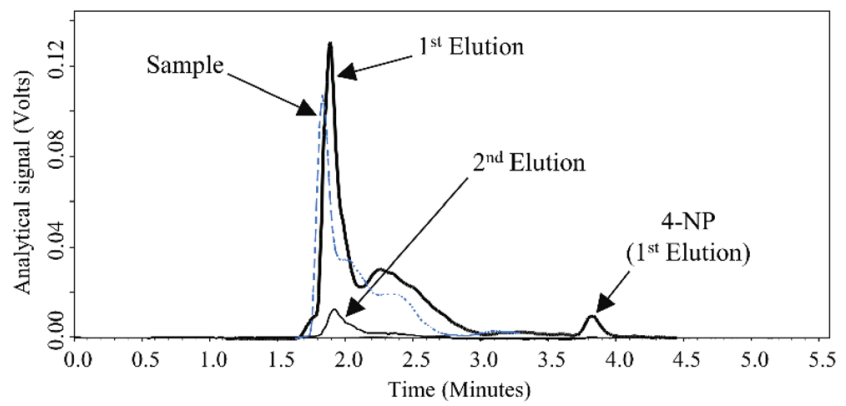

Figure 4. Chromatograms of 4-NP performed by solid phase extraction with C18-ODS cartridge

Lee et al. ${ }^{14}$ also used C-18 cartridges for sample pretreatment to evaluate 4-NP occurrence in rivers but they observed $80.4 \pm 5.2 \%$ of recovery after extraction, which is lower than the present study $(100.7 \pm 9.1 \%)$. This may have occurred due to the conditioning and eluting procedure performed. The authors conditioned the $\mathrm{C}-18$ cartridges with $45 \mathrm{~mL} \mathrm{MeOH} /$ acetone $(1: 1, \mathrm{v} / \mathrm{v})$ followed by $10 \mathrm{~mL}$ of ultrapure water. After sample addition the cartridges were eluted with $15 \mathrm{~mL} \mathrm{MeOH} /$ acetone $(1: 1, \mathrm{v} / \mathrm{v})$ and $5 \mathrm{~mL}$ of dichloromethane. In addition to the lower percentage of 4-NP recovery, the authors used a total of $75 \mathrm{~mL}$ of reagents, which is about 19 times higher than that used in the present study (4 mL).

Residue amount generated performing SPE at the present study was $4 \mathrm{~mL}$, composed by $3 \mathrm{~mL}$ of organic solvents $(2 \mathrm{~mL}$ of $\mathrm{MeOH}$ and $1 \mathrm{~mL}$ of EtOH) and $1 \mathrm{~mL}$ of ultrapure water. Thus, lower reagents volume compared to those described by Lee et al., ${ }^{14} \mathrm{Lu}$; Reif and $\mathrm{Gan}^{12}$ and Liu et al., ${ }^{12}$ which used total volumes of $75 \mathrm{~mL}, 60 \mathrm{~mL}$ and $20 \mathrm{~mL}$, respectively (Table 4). These results highlight that extraction and elution procedure were more economical and less polluting than previously reported.

\section{Method validation}

Household sewage and laundry wastewater are complex matrices due surfactants presence ${ }^{3}$ which can interfere in HPLC-FLD analysis. ${ }^{59}$ However, no peak overlap was observed at the 4-NP retention time. Method selectivity was analyzed with simulated substrate free of analyte (Figure $5 \mathrm{~A}$ ) and samples containing ultrapure water plus 4-NP (Figure $5 \mathrm{~B}$ ); these chromatograms show that no substance co-eluted at the same retention time of the target compound (4-NP).

Table 3. Assays of 4-NP adsorption in filtration membranes

\begin{tabular}{lcccc}
\hline Tests & Control & Cellulose & Reg. Cellulose & Glass fiber \\
\hline 1 & 3118.0 & 356.3 & 584.7 & 163.6 \\
2 & 3057.1 & 166.3 & 578.5 & 664.6 \\
3 & 2932.2 & 301.9 & 542.7 & 742.0 \\
4 & 2953.2 & 351.3 & 532.1 & 705.4 \\
5 & 2935.8 & 176.6 & 164.6 & 755.5 \\
\hline 4-NP recovered $\left(\mu \mathrm{g} \mathrm{L}^{-1}\right)$ & $2999.3 \pm 74.9$ & $270.5 \pm 83.1$ & $480.5 \pm 159.3$ & $606.2 \pm 223.6$ \\
Adsorption $(\%)$ & - & 91 & 84 & 80 \\
\hline
\end{tabular}

Control: unfiltered simulated substrate plus 4-NP; Cellulose: simulated substrate plus 4-NP filtered on $0.22 \mu \mathrm{m}$ cellulose acetate membrane; Reg. Cellulose: simulated substrate plus 4-NP filtered on $0.22 \mu \mathrm{m}$ regenerated cellulose membrane; Glass fiber: simulated substrate plus 4-NP filtered on $0.22 \mu \mathrm{m}$ glass fiber membrane. 
Table 4. Solid phase extraction (SPE) procedures previously reported for 4-NP determination

\begin{tabular}{|c|c|c|c|c|}
\hline Extraction parameters & Lu; Reif \& Gan ${ }^{12}$ & Lee et $a l .{ }^{14}$ & Liu et $a l .{ }^{12}$ & Present study \\
\hline Filtration Membrane & glass fiber $(0.5 \mu \mathrm{m})$ & glass fiber $(1.6 \mu \mathrm{m})$ & glass fiber $(0.45 \mu \mathrm{m})$ & Not used \\
\hline SPE Cartridges & Thermo Scientific $^{\circledR}$ & $\operatorname{Merck}^{\circledR}$ & Oasis $^{\circledR}$ & Agilent Technologies ${ }^{\circledR}$ \\
\hline Cartridges composition & $\begin{array}{l}\text { magnesia-loaded silica gel } \\
\quad(500 \mathrm{mg}, 6 \mathrm{~mL})\end{array}$ & C-18 (500 mg, $6 \mathrm{~mL})$ & $\begin{array}{l}\text { universal polymeric reversed- } \\
\text { phase }(500 \mathrm{mg}, 6 \mathrm{~mL})\end{array}$ & $\mathrm{C}-18$ (500 mg, $6 \mathrm{~mL})$ \\
\hline Conditioning step & $25 \mathrm{~mL}$ of $\mathrm{HEX}$ & $\begin{array}{l}45 \mathrm{~mL} \mathrm{MeOH} / \text { acetone at } 1: 1 \\
(\mathrm{v} / \mathrm{v}) \text { and } 10 \mathrm{~mL} \text { of } \mathrm{UW}\end{array}$ & $\begin{array}{l}5 \mathrm{~mL} \text { of } \mathrm{MeOH} \text { and } \\
5 \mathrm{~mL} \text { of } \mathrm{UW}\end{array}$ & $2 \mathrm{~mL}$ of $\mathrm{MeOH}$ \\
\hline Elution step & $35 \mathrm{~mL}$ of $\mathrm{DCM}$ & $\begin{array}{l}15 \mathrm{~mL} \text { de } \mathrm{MeOH} / \text { acetone at } \\
1: 1(\mathrm{v} / \mathrm{v}) \text { and } 5 \mathrm{~mL} \text { of } \mathrm{DCM}\end{array}$ & $10 \mathrm{~mL}$ of $\mathrm{MeOH}$ & $\begin{array}{l}1 \mathrm{~mL} \text { of } \mathrm{EtOH} \text { and } \\
1 \mathrm{~mL} \text { of } \mathrm{UW}\end{array}$ \\
\hline $4-\mathrm{NP}$ recovered $(\%)$ & $102 \pm 6$ & $80.4 \pm 5.2$ & 74.6 to 101.3 & $100.8 \pm 9.1$ \\
\hline Residue amount per sample & $60 \mathrm{~mL}$ & $75 \mathrm{~mL}$ & $20 \mathrm{~mL}$ & $4 \mathrm{~mL}$ \\
\hline
\end{tabular}

ACN - Acetonitrile; EtOH - ethanol; MeOH - methanol; UW - Ultrapure Water; HEX - Hexane; DCM - Dichloromethane.

Chromatographic peak of 4-NP was not observed after repeated injections of methanol, indicating that no carryover effect occurred within chromatographic system with this method. Selectivity was also verified in real complex matrices such as domestic sewage and commercial laundry wastewater (supplementary material, Figure $1 \mathrm{~S}$ ) and in none of the evaluated samples were detected interfering chromatographic peaks at the retention time of 4-NP.

Analytical curve (Figure $5 \mathrm{C}$ ) was determined from $55.6 \mu \mathrm{g} \mathrm{L}^{-1}$ to $3250.0 \mu \mathrm{g} \mathrm{L}^{-1}$ of 4-NP, with linear regression coefficient of 0.9951. Relative standard deviation (RSD\%) was lower than $20 \%$ in all curve concentrations, which attends $\mathrm{EPA}^{55}$ recommendation. The limits of detection (LOD) and quantification (LOQ) were $15.7 \mu \mathrm{g} \mathrm{L}^{-1}$ and $55.6 \mu \mathrm{g} \mathrm{L}^{-1}$, respectively. LOD and LOQ change according to the instrument, chromatographic parameters and reagents used, ${ }^{42,60}$ where frequently reported values in chromatographic methods for 4-NP determination range from $2.0 \mathrm{ng} \mathrm{L}^{-1}$ (LOD) and $6.0 \mathrm{ng} \mathrm{L}^{-1}$ (LOD) for surface water samples ${ }^{23}$ to $110.0 \mu \mathrm{g} \mathrm{L^{-1 }}$ (LOD) and $1100.0 \mu \mathrm{g} \mathrm{L}^{-1}$ (LOD) in effluents from biological reactors. ${ }^{8}$

\section{Method application - Anaerobic batch reactors}

Physicochemical parameters, 4-NP removal and methane production Anaerobic batch reactors were monitored during $217.8 \pm 13.6 \mathrm{~h}$
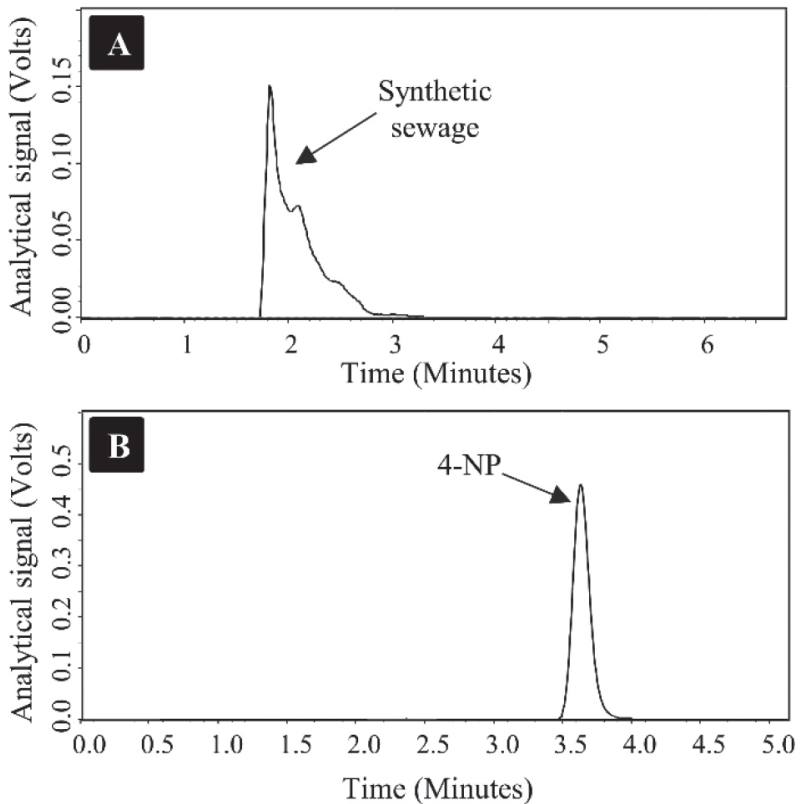

for control assays (EtOH, MeOH e Fum) and 420.4 $\pm 36.7 \mathrm{~h}$ for 4-NP addition $\left(\mathrm{EtOH}_{\mathrm{NP}}, \mathrm{MeOH}_{\mathrm{NP}}\right.$ e Fum $\left.\mathrm{NP}_{\mathrm{NP}}\right)$.

Initial organic matter values were $1183.3 \pm 11.3 \mathrm{mg} \mathrm{COD} \mathrm{L}^{-1}$, $883.3 \pm 43.8 \mathrm{mg} \mathrm{COD} \mathrm{L}^{-1}$ and $1160.8 \pm 36.7 \mathrm{mg} \mathrm{COD} \mathrm{L}^{-1}$ for the $\mathrm{EtOH}, \mathrm{MeOH}$ and Fum, respectively. For assays with 4-NP addition the initial organic matter values were $1305.2 \pm 7.4 \mathrm{mg} \mathrm{COD} \mathrm{L}^{-1}$, $914.8 \pm 8.9 \mathrm{mg} \mathrm{COD} \mathrm{L}^{-1}$ and $1242.0 \pm 27.5 \mathrm{mg} \mathrm{COD} \mathrm{L}^{-1}$ for $\mathrm{EtOH}_{\mathrm{NP}}$, $\mathrm{MeOH}_{\mathrm{NP}}$ and Fum $\mathrm{NP}$, respectively. Organic matter removal efficiencies of control reactors were $85.1 \pm 0.4 \%, 82.5 \pm 0.3 \%$ and $77.7 \pm 0.9 \%$ for the Fum, EtOH and $\mathrm{MeOH}$, respectively. For the assays with 4-NP addition the efficiency of organic matter removal followed the same behavior of the control assays and values were $75.5 \pm 0.3 \%$, $60.7 \pm 0.6 \%$ and $60.4 \pm 1.0 \%$ for $\mathrm{Fum}_{\mathrm{NP}} ; \mathrm{EtOH}_{\mathrm{NP}}$ and $\mathrm{MeOH}_{\mathrm{NP}}$, respectively. (Table 5)

Greater organic matter removal efficiencies occurred in the assays with fumarate addition (Fum and Fum $_{\mathrm{NP}}$ ), which were statistically different (Tukey test, $p=0.05$ ) from the others. Probably, this cosubstrate favored the benzyl-succinate formation, following the metabolic pathway of fumarate-succinate, as previously described by Heider et al. ${ }^{61,62}$ Fumarate addition can increase the aromatic compounds degradation by the formation of benzyl succinate as mentioned by Fuchs et al. ${ }^{61}$ which helped to remove the organic load applied to batch reactors.

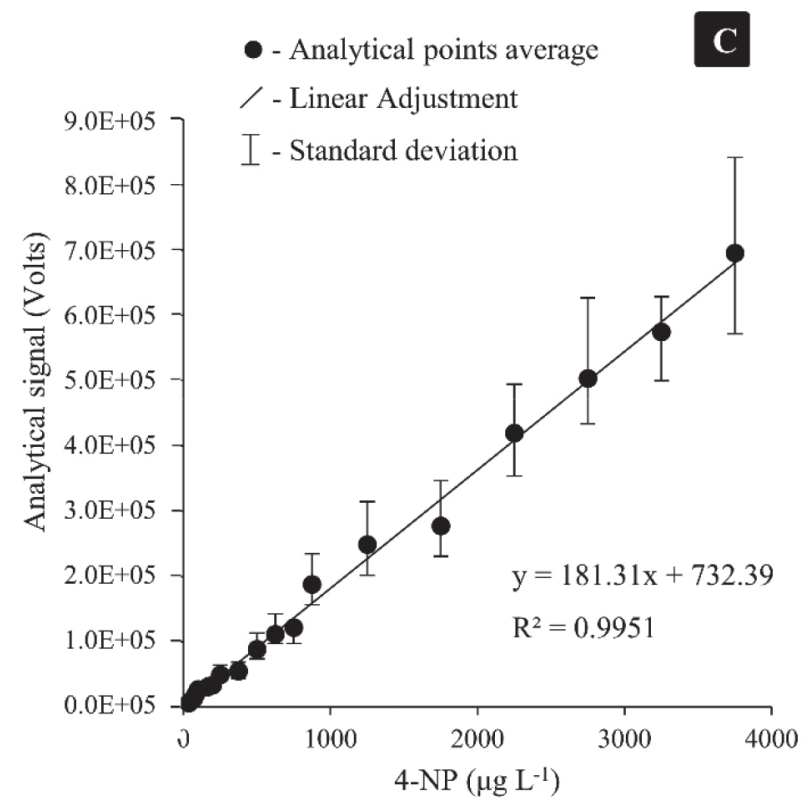

Figure 5. (A) Chromatogram of simulated substrate free of 4-NP, (B) chromatogram of ultrapure water plus 4-NP (C) analytical curve of 4-NP determination, standard deviation and linear fit 
Table 5. Values of the physical-chemical parameters, 4-NP removal and methane production

\begin{tabular}{|c|c|c|c|c|c|c|}
\hline & $\mathrm{EtOH}$ & $\mathrm{MeOH}$ & Fum & $\mathrm{EtOH}_{\mathrm{NP}}$ & $\mathrm{MeOH}_{\mathrm{NP}}$ & Fum $_{\mathrm{NP}}$ \\
\hline & \multicolumn{6}{|c|}{ Chemical Oxygen Demand (COD) } \\
\hline Initial $\left(\mathrm{mg} \mathrm{L}^{-1}\right)$ & $1183.3 \pm 11.3$ & $883.3 \pm 43.8$ & $1160.8 \pm 36.7$ & $1305.2 \pm 7.4$ & $914.8 \pm 8.9$ & $1242.0 \pm 27.5$ \\
\hline Final $\left(\mathrm{mg} \mathrm{L}^{-1}\right)$ & $208.0 \pm 4.1$ & $194.5 \pm 3.1$ & $170.0 \pm 2.5$ & $512.4 \pm 6.2$ & $362.3 \pm 8.6$ & $304.0 \pm 4.2$ \\
\hline \multirow[t]{2}{*}{ Efficiency (\%) } & $82.5 \pm 0.3$ & $77.8 \pm 0.9$ & $85.1 \pm 0.4$ & $60.7 \pm 0.6$ & $60.4 \pm 1.0$ & $75.5 \pm 0.3$ \\
\hline & \multicolumn{6}{|c|}{ Initial Alkalinity } \\
\hline Total $\left(\mathrm{mg} \mathrm{CaCO} \mathrm{L}^{-1}\right)$ & 196.7 & 197.5 & 258.5 & 124.2 & 125.7 & 271.4 \\
\hline $\operatorname{Partial}\left(\mathrm{mg} \mathrm{CaCO}_{3} \mathrm{~L}^{-1}\right)$ & 147.9 & 147.2 & 145.8 & 96.2 & 94.8 & 155.1 \\
\hline Intermediate $\left(\mathrm{mg} \mathrm{CaCO}_{3} \mathrm{~L}^{-1}\right)$ & 48.8 & 50.3 & 112.7 & 28.0 & 30.9 & 116.3 \\
\hline $\mathrm{IA} / \mathrm{PA}$ & 0.33 & 0.34 & 0.77 & 0.29 & 0.33 & 0.75 \\
\hline \multirow[t]{2}{*}{$\mathrm{pH}$} & 7.79 & 7.83 & 7.79 & 8.00 & 7.93 & 7.75 \\
\hline & \multicolumn{6}{|c|}{ Final Alkalinity } \\
\hline Total $\left(\mathrm{mg} \mathrm{CaCO} \mathrm{Ca}_{3} \mathrm{~L}^{-1}\right)$ & 511.9 & 508.3 & 756.1 & 592.4 & 579.4 & 883.9 \\
\hline Partial $\left(\mathrm{mg} \mathrm{CaCO}_{3} \mathrm{~L}^{-1}\right)$ & 387.7 & 405.7 & 599.5 & 435.8 & 416.4 & 701.5 \\
\hline Intermediate $\left(\mathrm{mg} \mathrm{CaCO}_{3} \mathrm{~L}^{-1}\right)$ & 124.2 & 102.7 & 156.5 & 156.5 & 162.9 & 182.4 \\
\hline $\mathrm{IA} / \mathrm{PA}$ & 0.32 & 0.25 & 0.26 & 0.36 & 0.39 & 0.26 \\
\hline \multirow[t]{2}{*}{$\mathrm{pH}$} & 7.28 & 7.41 & 7.50 & 7.52 & 7.61 & 7.50 \\
\hline & \multicolumn{6}{|c|}{ 4-NP } \\
\hline Initial $\left(\mu \mathrm{g} \mathrm{L}^{-1}\right)$ & - & - & - & $289.0 \pm 96.5$ & $470.0 \pm 182.4$ & $435.8 \pm 70.4$ \\
\hline Final $\left(\mu \mathrm{g} \mathrm{L}{ }^{-1}\right)$ & - & - & - & $52.9 \pm 41.9$ & $110.9 \pm 50.4$ & $212.6 \pm 9.3$ \\
\hline \multirow[t]{2}{*}{ Efficiency (\%) } & - & - & - & $81.4 \pm 14.3$ & $73.7 \pm 16.6$ & $50.6 \pm 5.7$ \\
\hline & \multicolumn{6}{|c|}{ Methane production } \\
\hline $\mathrm{R}^{2}$ & 0.9839 & 0.9464 & 0.9715 & 0.9896 & 0.9960 & 0.9908 \\
\hline Accumulated methane production $(\mu \mathrm{mol})$ & $2849.4 \pm 107.4$ & $1721.8 \pm 108.6$ & $2305.8 \pm 85.0$ & $2883.5 \pm 180.9$ & $2187.1 \pm 57.8$ & $3163.7 \pm 169.2$ \\
\hline Methane production rate $\left(\mu \mathrm{mol} \mathrm{h} \mathrm{h}^{-1}\right)$ & $26.7 \pm 2.7$ & $16.7 \pm 3.0$ & $29.9 \pm 4.8$ & $11.5 \pm 1.1$ & $9.5 \pm 0.5$ & $11.8 \pm 0.7$ \\
\hline Start-up time (h) & $17.4 \pm 5.0$ & $11.0 \pm 8.8$ & $19.1 \pm 5.5$ & $122.0 \pm 10.3$ & $112.3 \pm 5.6$ & $89.4 \pm 6.8$ \\
\hline
\end{tabular}

$\mathrm{EtOH}$ - ethanol as co-substrate in simulated substrate; $\mathrm{MeOH}$ - methanol as co-substrate in simulated substrate; Fum - sodium fumarate as co-substrate in simulated substrate; $\mathrm{EtOH}_{\mathrm{NP}}-$ ethanol as co-substrate in simulated substrate plus 4-NP; $\mathrm{MeOH}_{\mathrm{NP}}-$ methanol as co-substrate in simulated substrate plus 4-NP; Fum $_{\mathrm{NP}}-$ sodium fumarate as co-substrate in simulated substrate plus 4-NP.

The initial $\mathrm{pH}$ of the anaerobic reactors remained between 7.7 and 8.0, whereas for the final values ranged from 7.3 to 7.6 . The 4-NP addition in anaerobic reactors decreased the total, partial and intermediate alkalinity in the $\mathrm{EtOH}_{\mathrm{NP}}$ and $\mathrm{MeOH}_{\mathrm{NP}}$ assays. On the other hand, in Fum $\mathrm{NP}_{\mathrm{N}}$ assay was observed the reduction of total, partial and intermediate alkalinity. This behavior may have occurred because of the higher efficiency of organic matter removal verified in Fum $_{\mathrm{NP}}$ assay $(75.5 \pm 0.3 \%)$, indicating adequate use of organic acids to methane production and other metabolic byproducts such as $\mathrm{H}_{2}$ and $\mathrm{CO}_{2}$. ${ }^{63}$

Greater 4-NP removal efficiency $(81.4 \pm 14.3 \%)$ occurred in the $\mathrm{EtOH}_{\mathrm{NP}}$ assay for 4-NP initial concentration of $289.0 \pm 96.5 \mu \mathrm{g} \mathrm{L}^{-1}$, which may be related to the fact that ethanol is a readily biodegradable carbon source. ${ }^{64}$ However, no statistical difference was observed by Tukey test at $5 \%$ and $10 \%$ error probability when compared to the other assays $\left(\mathrm{MeOH}_{\mathrm{NP}}\right.$ and $\left.\mathrm{Fum}_{\mathrm{NP}}\right)$, because the high standard deviation between replicates (Table 5). This results may be related to hydrophobic character of 4-NP; due its low solubility in water $\left(\mathrm{K}_{\mathrm{ow}} \log \right.$ of 4.48) it tends to adsorb in the organic portion such as sludge from wastewater treatment plants. ${ }^{14,18,19,65,66}$ Adsorption phenomenon may have occurred in present study and contributed to the high standard deviations of initial, final and 4-NP removal efficiency.

Accumulated methane production was greater for the 4-NP addition assays $\left(\mathrm{EtOH}_{\mathrm{NP}}, \mathrm{MeOH}_{\mathrm{NP}}\right.$ and $\left.\mathrm{Fum}_{\mathrm{NP}}\right)$ when compared to control (EtOH, MeOH and Fum). The 4-NP addition increased biomass adaptation time and decreased the methane production rate in all experimental conditions (Table 5), which created two distinct profiles in the cumulative methane production curves (Figure 6). Fumarate was the best co-substrate to favor methane production with 4-NP addition and 3163.7 $\pm 169.2 \mu$ mol of methane at headspace was observed for the Fum $\mathrm{NP}_{\mathrm{NP}}$ assay, which also provided higher removal efficiency of organic matter $(75.5 \pm 0.3 \%)$, lower start-up time for methane production $(89.4 \pm 6.8 \mathrm{~h})$ and a higher methane production speed $\left(11.8 \pm 0.7 \mu \mathrm{mol} \mathrm{h}^{-1}\right)$, for $1242.0 \pm 27.5 \mathrm{mg} \mathrm{COD} \mathrm{L}^{-1}$ of initial organic matter concentration. These results support that fumarate addition may have contribute to both organic matter removal process and methanogenesis.

Lower accumulated methane production occurred in assays with methanol for both control $(\mathrm{MeOH}, 1721.8 \pm 108.6 \mu \mathrm{mol})$ and with 4-NP addition $\left(\mathrm{MeOH}_{\mathrm{NP}}, 2187.1 \pm 57.7 \mu \mathrm{mol}\right)$. Lower methane production speed was also observed in methanol assays for both control $\left(\mathrm{MeOH}, 16.7 \pm 3.0 \mu \mathrm{mol} \mathrm{h} \mathrm{h}^{-1}\right)$ and 4-NP addition $\left(\mathrm{MeOH}_{\mathrm{NP}}, 9.5 \pm 0.5 \mu \mathrm{mol} \mathrm{h}{ }^{-1}\right)$. This results may be related to the fact that methanol can be used by hydrogenotrophic methanogenic archaea under anaerobic conditions at the presence of bicarbonate, with $\mathrm{pH} \sim 7 .{ }^{67} \mathrm{On}$ the other hand, when the $\mathrm{pH}$ is close to 5 (with no bicarbonate), methanol is converted to acetic acid and favor acetoclastic microorganisms growth, which are greater responsible 


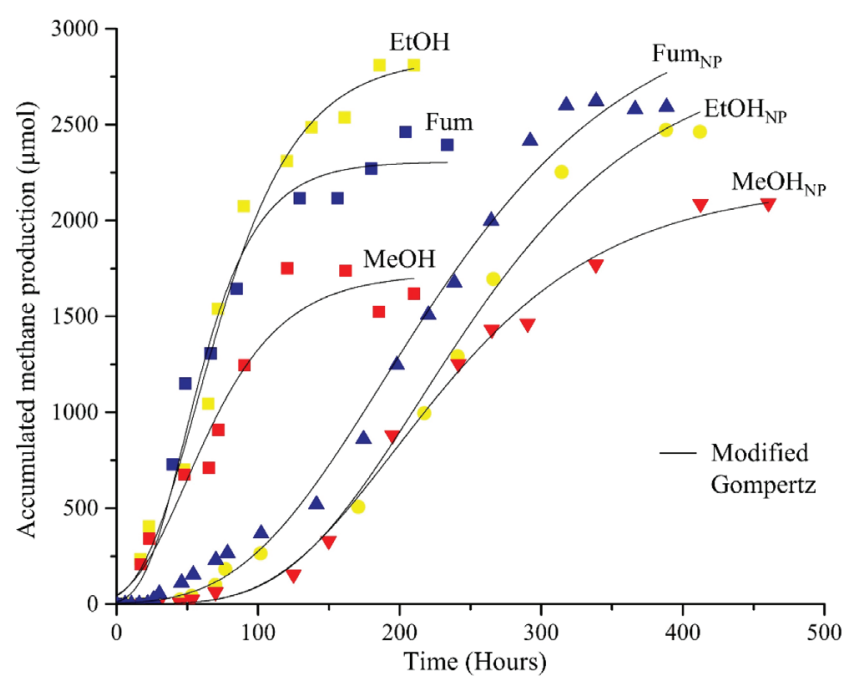

Figure 6. Cumulative methane production in control and 4-NP assays in anaerobic batch reactors. EtOH - ethanol as co-substrate in simulated substrate; $\mathrm{MeOH}$ - methanol as co-substrate in simulated substrate; Fum sodium fumarate as co-substrate in simulated substrate; $\mathrm{EtOH}_{N P}$ - ethanol as co-substrate in simulated substrate plus 4-NP; $\mathrm{MeOH} \mathrm{H}_{N P}-$ methanol as co-substrate in simulated substrate plus 4-NP; Fum N $_{N P}$ sodium fumarate as co-substrate in simulated substrate plus 4-NP

for methane production, besides its higher growth rate. ${ }^{68}$ So, the use of methanol in this study favored the growth of the hydrogenotrophic methanogenic archaea, which convert the substrate into a smaller portion of methane and have a lower growth rate when compared to the acetoclastic archaea. This explain the lower methane production for both control $(\mathrm{MeOH})$ and 4-NP addition assays $\left(\mathrm{MeOH}_{\mathrm{NP}}\right)$.

These results are in agreement with those reported by Motteran et al. ${ }^{45}$ which also observed decrease on methane production speed and increase on start time for methane production in batch reactors with anionic (LAS) and nonionic (LAE) surfactant addition. Higher efficiency of organic matter removal was $79.4 \pm 16 \%$ with initial LAE of $24.1 \pm 0.7 \mathrm{mg} \mathrm{L}^{-1}$ and $86.2 \pm 2.8 \%$ with initial LAS of $75.4 \pm 7.5 \mathrm{mg} \mathrm{L}^{-1}$. The authors noticed that surfactants increased $26 \%$ the accumulated methane production $(783.3 \pm 20.6 \mu \mathrm{mol})$ for LAE and $27 \%$ (1141.8 $\pm 65.5 \mu \mathrm{mol})$ for LAS addition, but decreased the methane production rate $(28.1 \pm 4.9 \mu \mathrm{mol} / \mathrm{d}$ for LAE and $8.2 \pm 1.7 \mu \mathrm{mol} / \mathrm{d}$ for LAS). According with Esposito et al. ${ }^{69}$ substrates biodegradability affects the accumulated methane production during the initial phase of organic matter conversion and increase adaptation time, as observed at present study (Figure 6). In this way, the presence of inhibitors such as 4-NP may be the main cause of the lower rate of methane production, since it requires more time for metabolic adaptation of microbial community.

\section{Effects on microbial community}

By cluster analysis of the DGGE band profile, all tested conditions changed microbial populations for both Archaea and Bacteria domains, when compared to the inoculum. The lowest similarity occurred among inoculum and the other assays, for both Archaea (82\%) (Figure 7A) and Bacteria domain (40\%) (Figure 7C). These results may have occurred because of the switch in reaction configuration and nutritional composition.

Similarity coefficients for the Archaea domain were 98\% (between the $\mathrm{EtOH}$ and $\mathrm{EtOH}_{\mathrm{NP}}$ ), $96 \%$ (between $\mathrm{MeOH}$ and $\mathrm{MeOH}_{\mathrm{NP}}$ ) and $91 \%$ (between Fum and Fum ${ }_{\mathrm{NP}}$ ), as illustrate Figure 7A. High Similarity values indicates low changes in microbial populations by
4-NP presence. These findings may be related to the phenomenon that organisms of Archaea domain consume a limited variety of substrates, which are produced by acidogenic microorganisms from Bacteria domain. ${ }^{70}$ Besides, archaea can resist to several antimicrobial agents ${ }^{71}$ and changes in nutritional composition, ${ }^{72}$ which would explain why these populations were less affected by 4-NP.

The highest diversity was 1,964 and occurred for $\mathrm{EtOH}_{\mathrm{NP}}$, which also presented the lowest dominance (0.1722). The 4-NP increased diversity of Archaea domain in all co-substrates tested from 1.936 to $1.964\left(\mathrm{EtOH}\right.$ and $\left.\mathrm{EtOH}_{\mathrm{NP}}\right)$, from 1.862 to 1.902 $\left(\mathrm{MeOH}\right.$ and $\mathrm{MeOH}_{\mathrm{NP}}$ ) and from 1.269 to 1.348 (Fum and Fum $_{\mathrm{NP}}$ ) (Figure 7B). Lower diversity values observed in Fum $\mathrm{NP}_{\mathrm{NP}}$ did not mean decline of anaerobic process because in this assay occurred greater organic matter removal efficiency $(75.5 \pm 0.3 \%$ removal for initial of $\left.1242.0 \pm 27.5 \mathrm{mg} \mathrm{COD} \mathrm{L}^{-1}\right)$, greater accumulated methane production $(3163.7 \pm 169.2 \mu \mathrm{mol})$, higher methane production speed $\left(11.8 \pm 0.7 \mu \mathrm{mol} \mathrm{h}^{-1}\right)$ and lowest start-up time for methane production $(89.4 \pm 6.8 \mathrm{~h})$, compared to $4-\mathrm{NP}$ assays $\left(\mathrm{EtOH}_{\mathrm{NP}}\right.$ and $\left.\mathrm{MeOH}_{\mathrm{NP}}\right)$ as shown in Table 5.

Similarity coefficients for Bacteria domain were $96 \%$ (between Fum and $\mathrm{Fum}_{\mathrm{NP}}$ ), 96\% (between and $\mathrm{EtOH}$ e $\mathrm{MeOH}$ ) and $73 \%$ (between $\mathrm{EtOH}_{\mathrm{NP}}$ e $\mathrm{MeOH}_{\mathrm{NP}}$ ). 4-NP reduced similarity among alcohols assays from $96 \%$ (between $\mathrm{EtOH}$ and $\mathrm{MeOH}$ ) to $45 \%$ (between $\mathrm{EtOH}_{\mathrm{NP}}$ and $\mathrm{MeOH}_{\mathrm{NP}}$ ) (Figure $7 \mathrm{C}$ ). Similarity reduction with 4-NP addition may be related to the establishment of new microbial communities since diversity increased from 2.421 (EtOH) to $2.642\left(\mathrm{EtOH}_{\mathrm{NP}}\right)$ in ethanol assays and from $2.610(\mathrm{MeOH})$ to $2.663\left(\mathrm{MeOH}_{\mathrm{NP}}\right)$ in methanol assays. Bacteria diversity increased and dominance decreased in all assays with 4-NP addition $\left(\mathrm{EtOH}_{\mathrm{NP}}\right.$, $\mathrm{MeOH}_{\mathrm{NP}}$ e Fum $\mathrm{NP}_{\mathrm{NP}}$ ), compared to control assays (EtOH, MeOH and Fum) (Figure 7D), which follows the same behavior observed for the Archaea domain (Figure 7B).

Use of fumarate as co-substrate promoted greater diversity for the Bacteria domain and the values increased from 2.673 (Fum) to 2.721 $\left(\right.$ Fum $\left._{\mathrm{NP}}\right)$ at $4-\mathrm{NP}$ initial concentration of $435.8 \pm 70.4 \mu \mathrm{g} \mathrm{L}^{-1}$. Increased in Bacteria domain diversity may have contributed to the interaction among the populations of the domains and the establishment of a central acetoclastic pathway for methane production, ${ }^{68}$ which conditioned the behavior of Archaea Domain populations. This finding strongly reinforces that fumarate may be a viable alternative to anaerobic process benefits in the presence of endocrine disruptors such as 4-NP.

The 4-NP increased diversity for both Archaea and Bacteria domains in all batch reactors and these finding may be related to the complexity of the metabolic process for this micropollutant degradation. According to Fuchs et al., ${ }^{61}$ aromatic compounds degradation under anaerobic conditions are performed by peripheral pathways, leading to a common central route. Peripheral degradation routes are specific to each organism and the 4-NP presence may have subsidized the establishment of these organisms and, consequently, increased diversity of microbial consortium. In addition, the stress caused by the nutritional switch and addition of toxic compound may causes the exchange of cellular material between organisms ${ }^{73}$ and helps them to adapt to the new condition.

\section{CONCLUSIONS}

A chromatographic method was developed for 4-NP determination, prioritizing alternatives to reduce reagent consumption, sample treatment, energy costs, solvent consumption and waste generation. HPLC-FLD and SPE techniques were successfully performed for 4-NP determination in anaerobic batch reactor.

Better chromatographic parameters for 4-NP determination in HPLC-FLD were: column C-8 at $40{ }^{\circ} \mathrm{C}$, flow of $0.8 \mathrm{~mL} \mathrm{~min}{ }^{-1}$, 


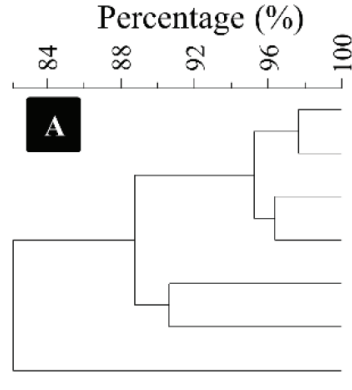

\section{$\stackrel{8}{9}$}
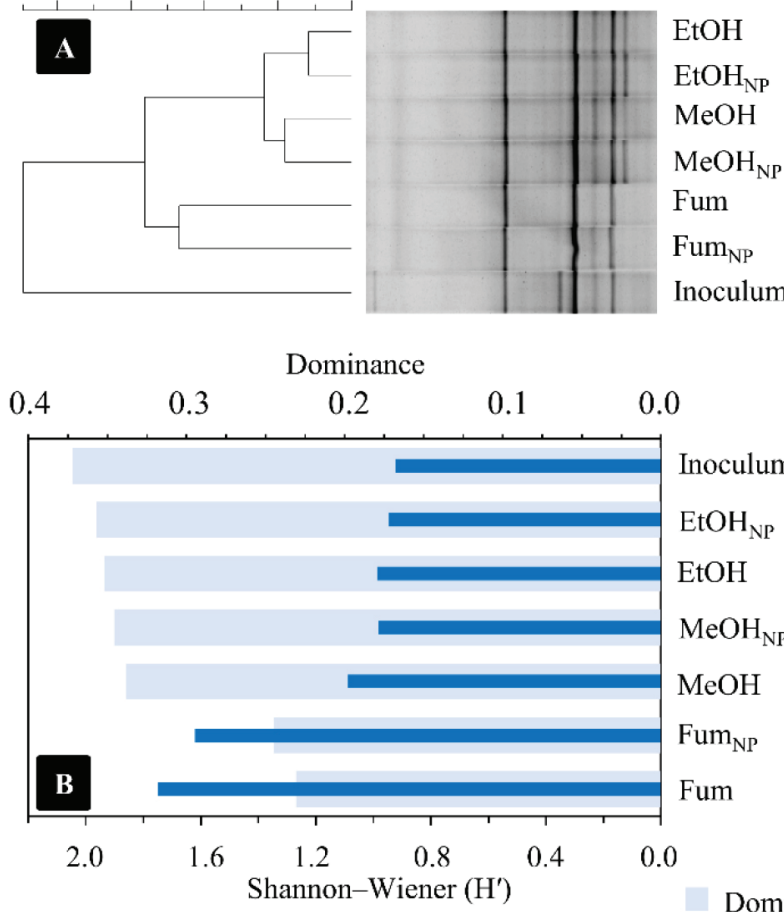

Inoculum

$\mathrm{EtOH}_{\mathrm{NP}}$

EtOH

$\mathrm{MeOH}_{\mathrm{NP}}$

$\mathrm{MeOH}$

Fum $_{\mathrm{NP}}$

Fum

0

Dominance index

Shannon-Wiener index (H')
Percentage $(\%)$
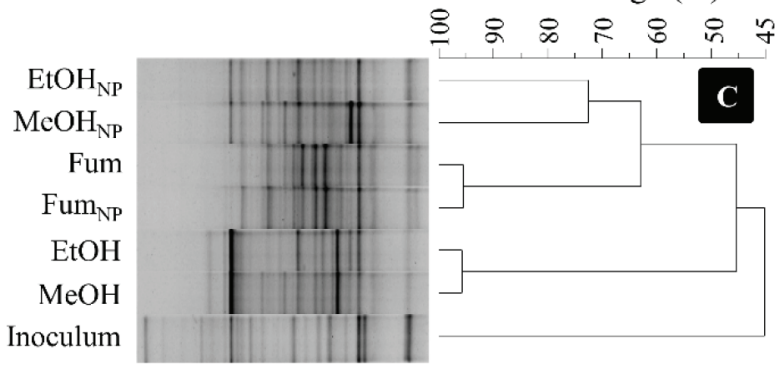

Dominance

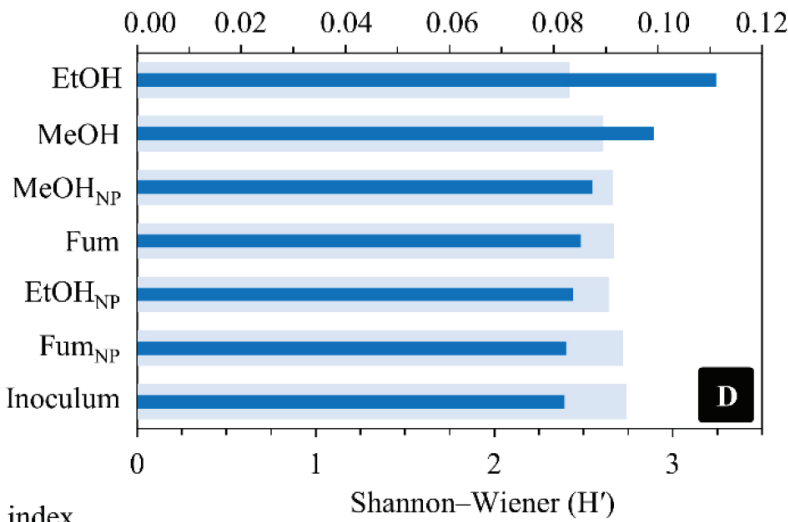

Figure 7. Dendrogram of similarity coefficient (Pearson correlation) of DGGE bands profile for the (A) Archaea Domain and (C) Bacteria Domain. Diversity (Shannon-Wiener) and dominance index for the (B) Archaea Domain and (D) Bacteria Domain. EtOH - ethanol as co-substrate in simulated substrate;

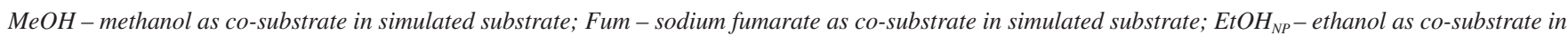

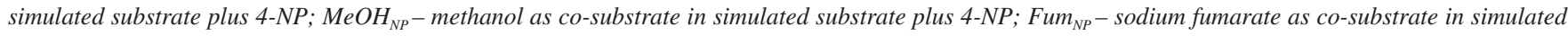
substrate plus 4-NP

injection volume of $100 \mu \mathrm{L}$, acetonitrile/water (90:10, v/v) as mobile phase and wavelengths for the fluorescence detector of $\lambda_{\mathrm{ex}}=225 \mathrm{~nm}$ and $\lambda_{\mathrm{em}}=305 \mathrm{~nm}$. These conditions allied to the use of SPE cartridges (C-18 ODS) led an efficient, high selective and robustness method for 4-NP determination. Optimized chromatographic conditions promoted a lower amount of residue generated, reduction in energy consumption and the use of solvents compared to the previously reported, i. e. cost reduction.

4-NP can be removed under anaerobic conditions but its presence decreases organic matter removal and methane production speed, increase the start-up time for methane production and influence the microbial diversity of anaerobic reactors in different co-substrates.

Fumarate is a better co-substrate to favor methanogenesis, which provide greater organic matter removal, higher methane production speed and shorter start-up time for methane production. These findings hardly suggest that fumarate addition may be an alternative to boost the anaerobic process during endocrine disrupters degradation, such as 4-NP.

\section{SUPPLEMENTARY MATERIAL}

Chromatograms of sewage and wastewater (Figure 1S) are freely available at http://quimicanova.sbq.org.br in pdf format.

\section{ACKNOWLEDGMENTS}

The authors gratefully acknowledge the Fundação de Amparo à Pesquisa do Estado de São Paulo (FAPESP), process number 2017 / 22850-7, the Conselho Nacional de Desenvolvimento Científico e
Tecnológico (CNPq) and the Coordenação de Aperfeiçoamento de Pessoal de Nível Superior - Brasil (CAPES) - Finance Code 001 by provided support for this study.

\section{REFERENCES}

1. Montagner, C.; Sodré, F.; Acayaba, R.; Vidal, C.; Campestrini, I.; Locatelli, M.; Pescara, I.; Albuquerque, A.; Umbuzeiro, G.; Jardim, W.; J. Braz. Chem. Soc. 2019, 30, 614.

2. Motteran, F.; Lima Gomes, P. C. F.; Silva, E. L.; Varesche, M. B. A.; Sci. Total Environ. 2017, 580, 1120.

3. Braga, J. K.; Varesche, M. B. A.; Am. J. Anal. Chem. 2014, 5, 8 .

4. Cruceru, I.; Iancu, V.; Petre, J.; Badea, I. A.; Vladescu, L.; Environ. Monit. Assess. 2012, 184, 2783.

5. Cherniaev, A. P.; Kondakova, A. S.; Zyk, E. N.; Achievements in the Life Sciences 2016, 10, 65.

6. Araujo, F. G. de; Bauerfeldt, G. F.; Cid, Y. P.; J. Braz. Chem. Soc. 2018, 29, 2046

7. Goel, A.; Müller, M. B.; Sharma, M.; Frimmel, F. H.; Acta Hydrochim. Hydrobiol. 2003, 31, 108.

8. Dornelles, H. de S.; Motteran, F.; Sakamoto, I. K.; Silva, E. L.; Varesche, M. B. A.; J. Environ. Manage. 2020, 267.

9. Wang, Z.; Yang, Y.; Sun, W.; Xie, S.; Liu, Y.; Ecotoxicol. Environ. Saf. 2014, 106, 1 .

10. Liu, J. F.; Liang, X.; Jiang, G. Bin; Cai, Y. Q.; Zhou, Q. X.; Liu, G. G.; J. Sep. Sci. 2003, 26, 823.

11. Xie, Y.; Ma, S.; Yuan, C.; Pan, Y.; Wang, Q.; Xu, Y.; Zhu, T.; Wang, Y.; Han, J.; You, M.; J. Braz. Chem. Soc. 2017, 28, 2438.

12. Lu, Z.; Reif, R.; Gan, J.; Water Res. 2015, 68, 282. 
13. Liu, D.; Wu, S.; Xu, H.; Zhang, Q.; Zhang, S.; Shi, L.; Yao, C.; Liu, Y.; Cheng, J.; Ecotoxicol. Environ. Saf. 2017, 140, 222.

14. Lee, C. C.; Jiang, L. Y.; Kuo, Y. L.; Hsieh, C. Y.; Chen, C. S.; Tien, C. $\mathrm{J} . ;$ Chemosphere 2013, 91, 904.

15. EPA; Aquatic life ambient water quality criteria nonylphenol, 2005.

16. Langford, K. H.; Lester, J. N. In Endocrine disrupters in wastewater and sludge treatment processes; Birkett, J. W., Lester, J. N., orgs.; Taylor \& Francis Group: London, 2002, cap. 4.

17. Salgueiro-González, N.; Turnes-Carou, I.; Besada, V.; MuniateguiLorenzo, S.; López-Mahía, P.; Prada-Rodríguez, D.; Sci. Total Environ. 2015, 529, 121.

18. Peng, F. J.; Pan, C. G.; Zhang, M.; Zhang, N. S.; Windfeld, R.; Salvito, D.; Selck, H.; Van den Brink, P. J.; Ying, G. G.; Sci. Total Environ. 2017, $589,46$.

19. Gorga, M.; Insa, S.; Petrovic, M.; Barceló, D.; Sci. Total Environ. 2015, 503-504, 69.

20. Diao, P.; Chen, Q.; Wang, R.; Sun, D.; Cai, Z.; Wu, H.; Duan, S.; Sci. Total Environ. 2017, 584-585, 1100.

21. Fries, E.; Püttmann, W.; Atmos. Environ. 2004, 38, 2013.

22. Jiang, L.; Yang, Y.; Zhang, Y.; Liu, Y.; Pan, B.; Wang, B.; Lin, Y.; Sci. Rep. 2019, 9, 1.

23. Machado, K. C.; Grassi, M. T.; Vidal, C.; Pescara, I. C.; Jardim, W. F.; Fernandes, A. N.; Sodré, F. F.; Almeida, F. V.; Santana, J. S.; Canela, M. C.; Nunes, C. R. O.; Bichinho, K. M.; Severo, F. J. R.; Sci. Total Environ. 2016, 572, 138

24. Priac, A.; Morin-Crini, N.; Druart, C.; Gavoille, S.; Bradu, C.; Lagarrigue, C.; Torri, G.; Winterton, P.; Crini, G.; Arab. J. Chem. 2017 $10, \mathrm{~S} 3749$.

25. Loyo-Rosales, J. E.; Rosales-Rivera, G. C.; Lynch, A. M.; Rice, C. P.; Torrents, A.; J. Agric. Food Chem. 2004, 52, 2016.

26. Giger, W.; Brunner, P. H.; Schaffner, C.; Science 1984, 225, 623.

27. Bonefeld-Jørgensen, E. C.; Long, M.; Hofmeister, M. V.; Vinggaard, A. M.; Environ. Health Perspect. 2007, 115, 69.

28. Arevalo, M.; Azcoitia, I.; Garcia-segura, L. M.; Nat. Publ. Gr. 2015, 16, 17.

29. Forte, M.; Di Lorenzo, M.; Carrizzo, A.; Valiante, S.; Vecchione, C.; Laforgia, V.; De Falco, M.; Toxicology 2016, 357-358, 21.

30. El-Hefnawy, T.; Hernandez, C.; Stabile, L. P.; Reprod. Biol. 2017, 17, 185.

31. Bechi, N.; Ietta, F.; Romagnoli, R.; Jantra, S.; Cencini, M.; Galassi, G.; Serchi, T.; Corsi, I.; Focardi, S.; Paulesu, L.; Environ. Health Perspect. 2010, 118, 427.

32. Wu, J.-J.; Wang, K.-L.; Wang, S.-W.; Hwang, G.-S.; Mao, I.-F.; Chen, M.-L.; Wang, P. S.; Toxicology 2010, 268, 1.

33. Lee, H. J.; Chattopadhyay, S.; Gong, E. Y.; Ahn, R. S.; Lee, K.; Toxicol. Sci. 2003, 75, 40.

34. Sayed, A. E. D. H.; Hamed, H. S.; Ecotoxicol. Environ. Saf. 2017, 139, 97.

35. Duarte, I. C. S.; L. Oliveira, L.; Buzzini, A. P.; Adorno, M. A. T.; Varesche, M. B. A.; J. Braz. Chem. Soc. 2006, 17, 1360.

36. Barahona, F.; Turiel, E.; Martín-Esteban, A.; J. Chromatogr. Sci. 2011, 49, 243.

37. Lopes, D.; Bernardi, G.; Pinheiro, G.; Campedelli, R. R.; Souza, B. S. de; Carasek, E.; J. Chromatogr. A 2019, 41-47, 1602.

38. Carabajal, M. D.; Arancibia, J. A.; Escandar, G. M.; Talanta 2019, 197, 348.

39. Noori, L.; Ghanemi, K.; Chem. Pap. 2019, 73, 301.

40. Bennie, D. T.; Sullivan, C. A.; Lee, H. B.; Peart, T. E.; Maguire, R. J.; Sci. Total Environ. 1997, 193, 263.
41. Oliveira, L. L. de; Costa, R. B.; Okada, D. Y.; Vich, D. V.; Duarte, I. C. S.; Silva, E. L.; Varesche, M. B. A.; Bioresour. Technol. 2010, 101, 5112.

42. Cassiano, N. M.; Barreiro, J. C.; Martins, L. R. R.; Oliveira, R. V.; Cass, Q. B.; Quim. Nova 2009, 32, 1021.

43. Ribani, M.; Bottoli, C. B. G.; Collins, C. H.; Jardim, I. C. S. F.; Melo, L. F. C.; Quim. Nova 2004, 27, 771.

44. Macedo, T. Z.; Okada, D. Y.; Delforno, T. P.; Braga, J. K.; Silva, E. L.; Varesche, M. B. A.; Bioprocess Biosyst. Eng. 2015, 38, 1835.

45. Motteran, F.; Braga, J. K.; Sakamoto, I. K.; Varesche, M. B. A.; Int. Biodeterior. Biodegrad. 2014, 96, 198.

46. APHA-AWWA-WEF; Standard Methods for the Examination of Water and Wastewater, $23^{\mathrm{a}}$ ed., 2017.

47. Nübel, U.; Engelen, B.; Felske, A.; Snaidr, J.; Wieshuber, A.; Amann, R. I.; Ludwig, W.; Backhaus, H.; J. Bacteriol. 1996, 178, 5636.

48. Kudo, Y.; Nakajima, T.; Taro, M.; Oyaizu, H.; FEMS Microbiol. Ecol. 1997, 22, 39.

49. Muyzer, G.; de Waal, E. C.; Uitterlinden, A. G.; Appl. Environ. Microbiol. 1993, 59, 695.

50. Hammer, Ø.; Harper, D. A. T.; Ryan, P. D.; Palaeontol. Electron. 2001, $4,9$.

51. Zwietering, M. H.; Jongenburger, I.; Rombouts, F. M.; van 't Riet, K.; Appl. Environ. Microbiol. 1990, 56, 1875.

52. Peixoto, G.; Pantoja-Filho, J. L. R.; Agnelli, J. A. B.; Barboza, M.; Zaiat, M.; Appl. Biochem. Biotechnol. 2012, 3, 651.

53. Korany, M. A.; Mahgoub, H.; Haggag, R. S.; Ragab, M. A. A.; Elmallah, O. A.; J. Liq. Chromatogr. Relat. Technol. 2017, 40, 839.

54. Lanças, F. M.; Sci. Chromatogr. 2012, 4, 13.

55. EPA; Method 8000D 2014, 1

56. Gao, D.; Li, Z.; Guan, J.; Li, Y.; Ren, N.; Chemosphere 2014, 97, 130.

57. Lian, J.; Liu, J.; J. Environ. Sci. 2013, 25, 1511.

58. Shreve, M. J.; Brennan, R. A.; Water Res. 2019, 151, 318.

59. Trufelli, H.; Palma, P.; Famiglini, G.; Cappiello, A.; Mass Spectrom. Rev. 2011, 30, 491.

60. ICH; Validation of Analytical Procedures: Text and Methodology, 2005.

61. Fuchs, G.; Boll, M.; Heider, J.; Nat. Rev. Microbiol. 2011, 9, 803.

62. Heider, J.; Curr. Opin. Chem. Biol. 2007, 11, 188.

63. Stams, A.; Int. J. Gen. Mol. Microbiol. 1994, 66, 271.

64. Macedo, T. Z.; Silva, E. L.; Sakamoto, I. K.; Zaiat, M.; Varesche, M. B. A.; Bioprocess Biosyst. Eng. 2019, 42, 1547.

65. Petrovic, M.; Fernández-Alba, A. R.; Borrull, F.; Marce, R. M.; Mazo, E. G.; Barceló, D.; Environ. Toxicol. Chem. 2002, 21, 37.

66. Wang, B.; Dong, F.; Chen, S.; Chen, M.; Bai, Y.; Tan, J.; Li, F.; Wang, Q.; Ecotoxicol. Environ. Saf. 2016, 128, 133.

67. Florencio, L.; Field, J. A.; Lettinga, G.; Water Research 1995, 29, 915.

68. Detman, A.; Mielecki, D.; Pleśniak, Ł.; Bucha, M.; Janiga, M.; Matyasik, I.; Chojnacka, A.; Jędrysek, M. O.; Błaszczyk, M. K.; Sikora, A.; Biotechnol. Biofuels 2018, 11, 1.

69. Esposito, G.; Frunzo, L.; Liotta, F.; Panico, A.; Pirozzi, F.; Open Environ. Eng. J. 2012, 5, 1 .

70. Smith, K. S.; Ingram-Smith, C.; Trends Microbiol. 2007, 15, 150.

71. Khelaifia, S.; Drancourt, M.; Clin. Microbiol. Infect. 2012, 18, 841.

72. Cattony, E. B. M.; Chinalia, F. A.; Ribeiro, R.; Zaiat, M.; Foresti, E.; Varesche, M. B. A.; Biotechnol. Bioeng. 2005, 91, 244.

73. Benomar, S.; Ranava, D.; Cárdenas, M. L.; Trably, E.; Rafrafi, Y.; Ducret, A.; Hamelin, J.; Lojou, E.; Steyer, J. P.; Giudici-Orticoni, M. T.; Nat. Commun. 2015, 6, 1 . 